\title{
The Environmental Impact of Palm Oil: Introduction for Students of Tasmania University, Australia
}

\author{
Diana Chalil ${ }^{*}$, Riantri Barus' ${ }^{1}$ Esther Sorta Mauli Nababan', Hasanuddin ${ }^{3}$, \\ Rudy Sofyan', Tulus ${ }^{2}$ \\ ${ }^{1}$ Department of Agribusiness, Faculty of Agriculture, Universitas Sumatera Utara, Indonesia \\ ${ }^{2}$ Department of Mathematics, Faculty of Mathematics and Natural Science, Universitas Sumatera Utara, \\ Indonesia \\ ${ }^{3}$ Department of Agro-ecotechnology, Faculty of Agriculture, Universitas Sumatera Utara, Indonesia \\ ${ }^{4}$ Department of English Literature, Faculty of Cultural Science, Universitas Sumatera Utara, Indonesia
}

\begin{abstract}
Palm oil is one of the most demanded commodities globally, which has led to a significant increase in its production and raised issues regarding its environmental impact. However, many of these issues are not based on substantial evidence. To provide a proportional picture on the oil palm industry, Universitas Sumatera Utara (USU), the University of Tasmania (UTAS) and the Association of Indonesian Palm Oil Entrepreneurs (GAPKI) have collaborated to carry out this program. The program was conducted for seven days through classroom lectures and field trip activities, involving 14 students and two supervisors from UTAS and four USU students. Pre and post-tests were conducted to evaluate the impact of the program. The results showed changes in participants' knowledge and perception regarding the environmental, social, and economic effects of the oil palm industry. Therefore, this program could be considered an effective counter to misleading Indonesian palm oil industry issues.
\end{abstract}

Keywords: Oil palm industry, Knowledge, Perception, Environmental impact, Social impact, Economic impact

\begin{abstract}
Abstrak. Minyak kelapa sawit adalah salah satu komoditas yang permintaannya cukup tinggi di dunia. Hal tersebut menyebabkan terjadinya peningkatan produksi yang signifikan yang menimbulkan isu negatif tentang dampak terhadap penurunan kualitas lingkungan. Namun, banyak isu-isu teresebut yang muncul tanpa didasarkan pada bukti kuat. Untuk memberikan gambaran proporsional tentang industri kelapa sawit, program ini dilakukan dengan kerja sama antara Universitas Sumatera Utara (USU), Universitas Tasmania (UTAS) dan Asosiasi Pengusaha Kelapa Sawit Indonesia (GAPKI). Program ini dilakukan selama 7 hari dengan menggunakan
\end{abstract}

*Corresponding author at: Faculty of Agriculture, Universitas Sumatera Utara, Jl. Prof. Sofyan, No. 3 Kampus USU Medan, 210155, Indonesia

E-mail address: diana3@usu.ac.id 
metode pemberian materi di kelas dan kegiatan kunjungan lapangan, yang melibatkan 14 siswa dan 2 pendamping dari UTAS serta 4 siswa dari USU. Untuk mengevaluasi dampak program dilakukan pre dan post-test. Hasilnya menunjukkan perubahan dalam pengetahuan dan persepsi peserta tentang dampak lingkungan, sosial dan ekonomi dari industri kelapa sawit. Dengan demikian dapat disimpulkan bahwa program ini cukup efektif untuk menjawab isu yang tidak berdasar terhadap industri kelalpa sawit Indonesia.

Kata Kunci: Industri kelapa sawit, Pengetahuan, persepsi, Dampak lingkungan, Dampak sosial, Dampak ekonomi

Received June 162020 | Revised November 27 2020| Accepted November 302020

\section{Introduction}

Indonesia is the biggest palm oil-producing and exporting country globally, with production reaching 31 million tons per year [1]. Palm oil is one of the most traded, but at the same time, the most controversial commodities in global trade [2-3]. The high world market demand has led central palm oil-producing countries such as Indonesia and Malaysia to further increase their production. The significant expansion of oil palm plantations is considered one of the leading causes of tropical forest loss, biodiversity decrease and even climate change from time to time. These statements are widely spread worldwide, although many are not supported by sufficient and robust data and information. If the disproportionate perception continues, demand for Indonesian palm oil from various importing countries could be affected.

In 2013, Australia, the United States and the United Kingdom claimed that Indonesian CPO is among the list of products that were not environmentally friendly. Australia is among the countries that frequently debate oil palm issues, especially those related to the environment [4]. Fortunately, Australia also allocates considerable funds and efforts for environmental improvement. One of these efforts includes sending Australian students to Indonesia through the Colombo Plan scheme, organized by the RUILI Conservation Field Trip to Indonesia. By directly visiting, observing, and communicating with palm oil stakeholders, participants are expected to receive more accurate information about the palm oil industry's environmental impact. RUILI has then collaborated with Universitas Sumatera Utara (USU) to achieve this program's objectives, namely to provide perception, knowledge and a proportional description and explanation about the palm oil to students from the University of Tasmania as part of Australian end consumers. 


\section{Method}

This program was conducted for one month starting from preparation, coordination to implementation. The implementation took six days through a combination of classroom presentation and discussion at the USU Chancellor's Bureau Building, and a field trip to Blankahan and Bukit Lawang, Bahorok, Langkat. The classroom presentation is designed to provide the students with a comprehensive introduction about the Indonesian Palm Oil Industry, and a discussion session about the palm oil issues. This program is completed with the field trip to give the students empirical examples of the topic presented and discussed in the class. The field trip is believed to provide a long-term effect on ecological and environmental knowledge and attitude development $[5]$.

Preparation was carried out since May 2019 through e-mail communication between the USU team and the Office of International Affairs with Jack McNaught and Angus as RUILI representatives. This plan and agreement were written in a Letter of Intent of the Conservation Trip activities of the Colombo Plan (Appendix 1). The implementation was carried out for six days in Jakarta and eight days in Medan, attended by 14 UTAS students from various science fields and four USU students. The field trip visit to the Palm Oil Mill was jointly arranged with the Indonesian Palm Oil Entrepreneurs Association (GAPKI) on July 5, 2019, to P.T. United Kingdom Indonesia (PT UKINDO) - Anglo-Eastern Plantation (AEP) Group. This group is based in the U.K., with oil palm plantations and mills in Indonesia and Malaysia. The farm and mill selected as the field trip destination has been certified, thus giving empirical examples of sustainable palm oil management. The program was then continued with a visit to the orangutan habitat in Bahorok, mostly associated with oil palm issues. The fact that the orangutans are well developed in Bahorok may balance the Indonesian concern on Orangutan welfare. Bahorok also has an environmental education centre, which is expected to provide complete information from long experienced field experts [6]. The program's impact was estimated with pre- and post-tests about the students' perception before and after the Indonesian palm oil industry presentation. The tests used open questions to explore all perceptions and avoid tendencies to specific answers. Therefore the impact estimation was not statistically presented, but rather is a list of all students' responses. 


\section{Result and Discussion}

\subsection{Day 1: July 5 2019: Lecture on Palm Oil Industry}

The lecture was conducted at the USU Senate Room with 14 and 4 students from University of Tasmania (UTAS) and Universitas Sumatera Utara (USU), respectively, and staff from RUILI Plan Australia and USU International Office.
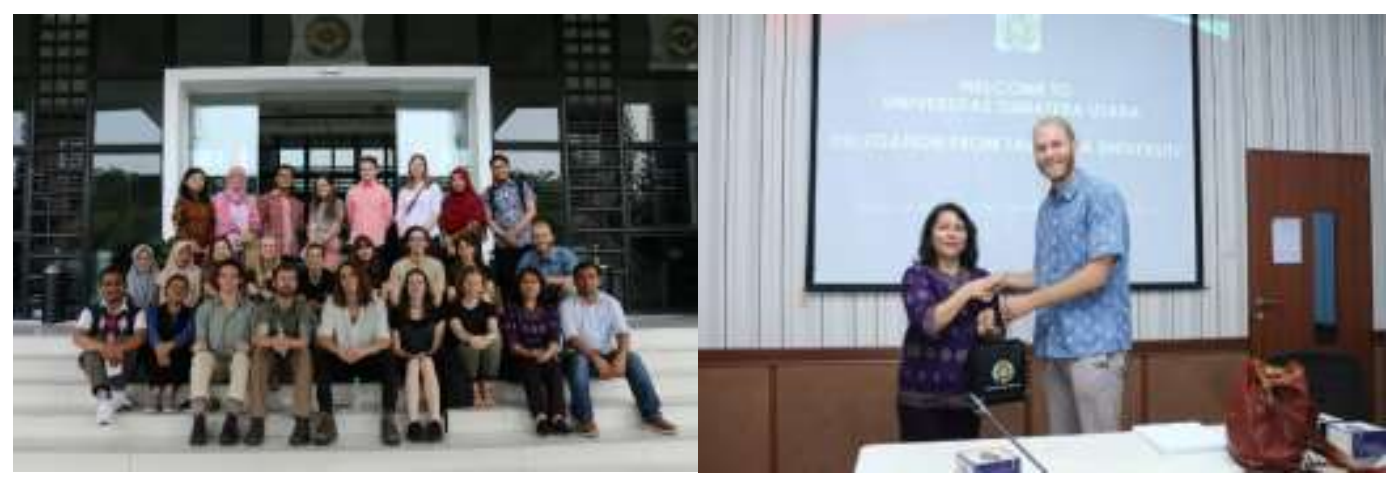

Figure 1. The Participants (left) and opening by the Head of International Office (right)

Mainly due to deforestation, health, biodiversity or orangutans. Several participants have read about the Indonesian palm oil industry's impact on economic growth and community income.

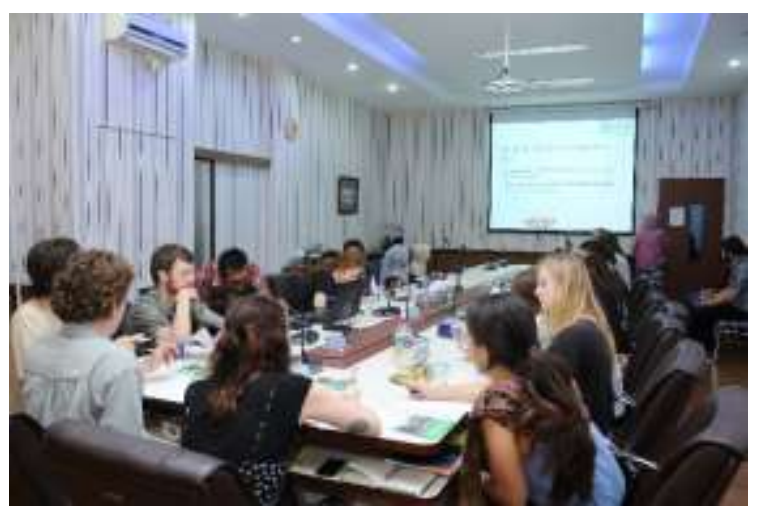

Figure 2. Pre-Test

Following this, a lecture titled "Inclusive Palm Oil Supply Chain" was presented by Diana Chalil, PhD.

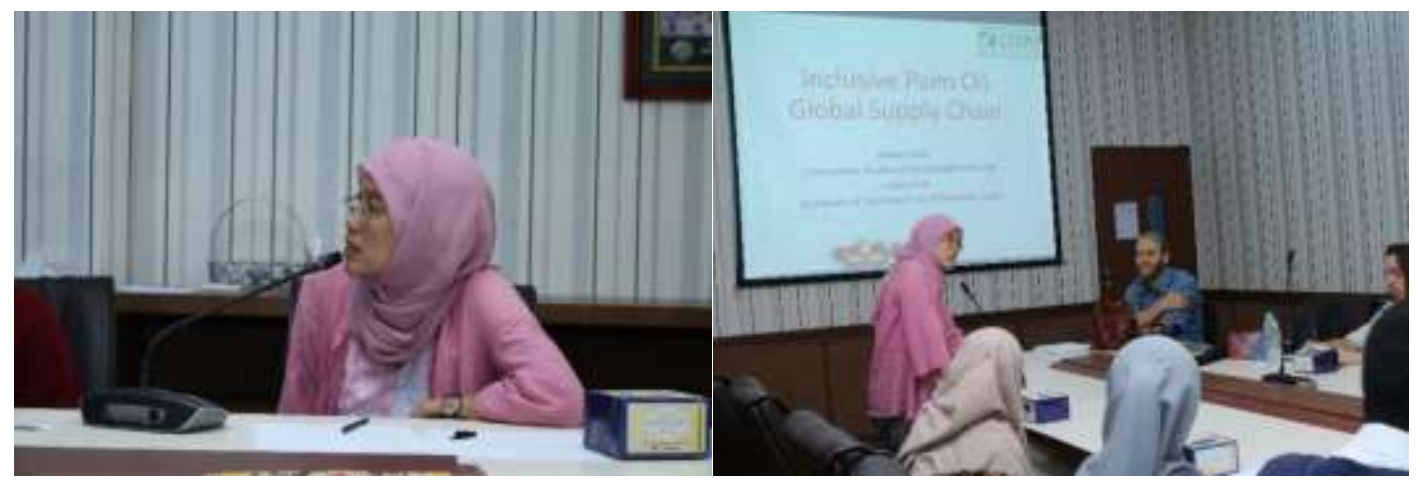

Figure 3. Presentation 
After the presentation, a question and answer session was held with UTAS students who showed high interest on matters related to (i) smallholding sustainability, (ii) mandatory certification, (iii) possibility multi-cropping in oil palm plantations, (iv) effectiveness of accreditation to improve sustainability, (v) possibility to make RSPO certification mandatory, (vi) opportunity to apply harvesting machines, (vii) corruption in regulations related to the palm oil industry, (viii) the development of science in the palm oil industry, (ix) the impact of the palm oil industry on smallholder income, (x) the possibility of developing organic palm oil, (xi) the genetic development of palm oil, (xii) the role of smallholdings, and (xiii) conditions of oil palm industry labours.

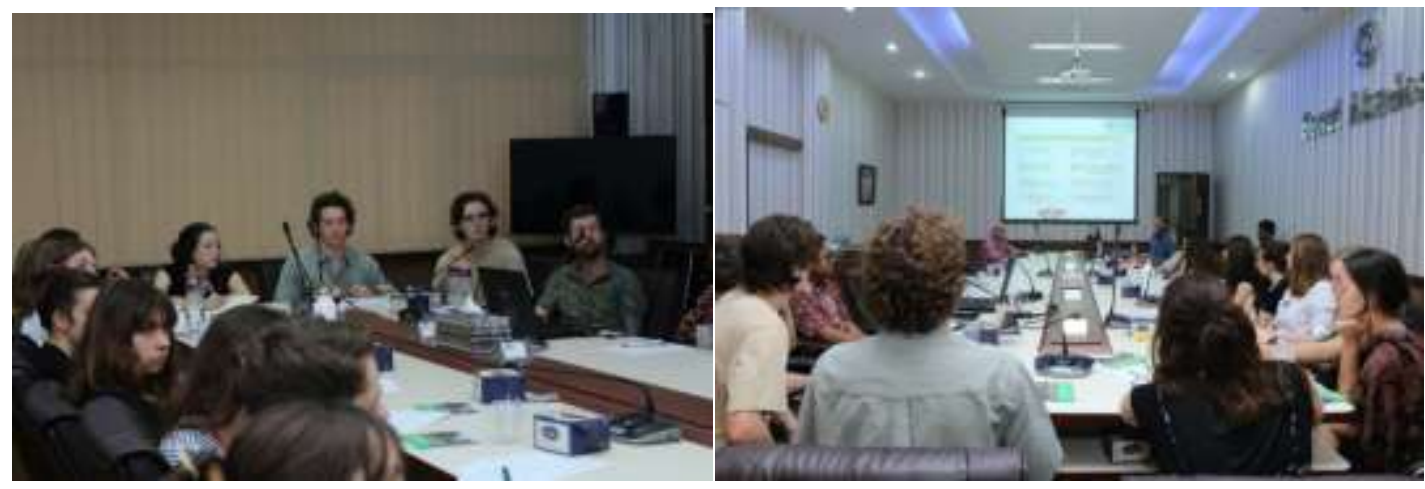

Figure 4. Question and Answer Session

Then, UTAS students were asked to take a post-test about the Indonesian palm oil industry. The results show significant changes in their perceptions. Almost all stated that oil palm is an essential commodity for producing countries like Indonesia and consumer countries like Australia. Students understand that the high demand for palm oil in the world market is mainly due to its excellent efficiency compared to other vegetable oils. However, the students still think that palm oil is a massive industry with complex issues, including deforestation and environmental risks.

\subsection{Day 2: July 6 2019: Field Trip to PT UKINDO}

To directly observe the sustainable management in palm oil companies, UTAS students visited a certified oil palm plantation and mill owned by PT UKINDO in Blangkahan Village, Langkat. Mr Reuban presented an explanation about sustainable management in plantations and mills as the manager of PT UKINDO. Following this, the students went to the ranch to observe the harvesting process. This mixed lecture and site visit approach appear to provide a clear and convincing explanation about sustainable management in the palm oil industry. 

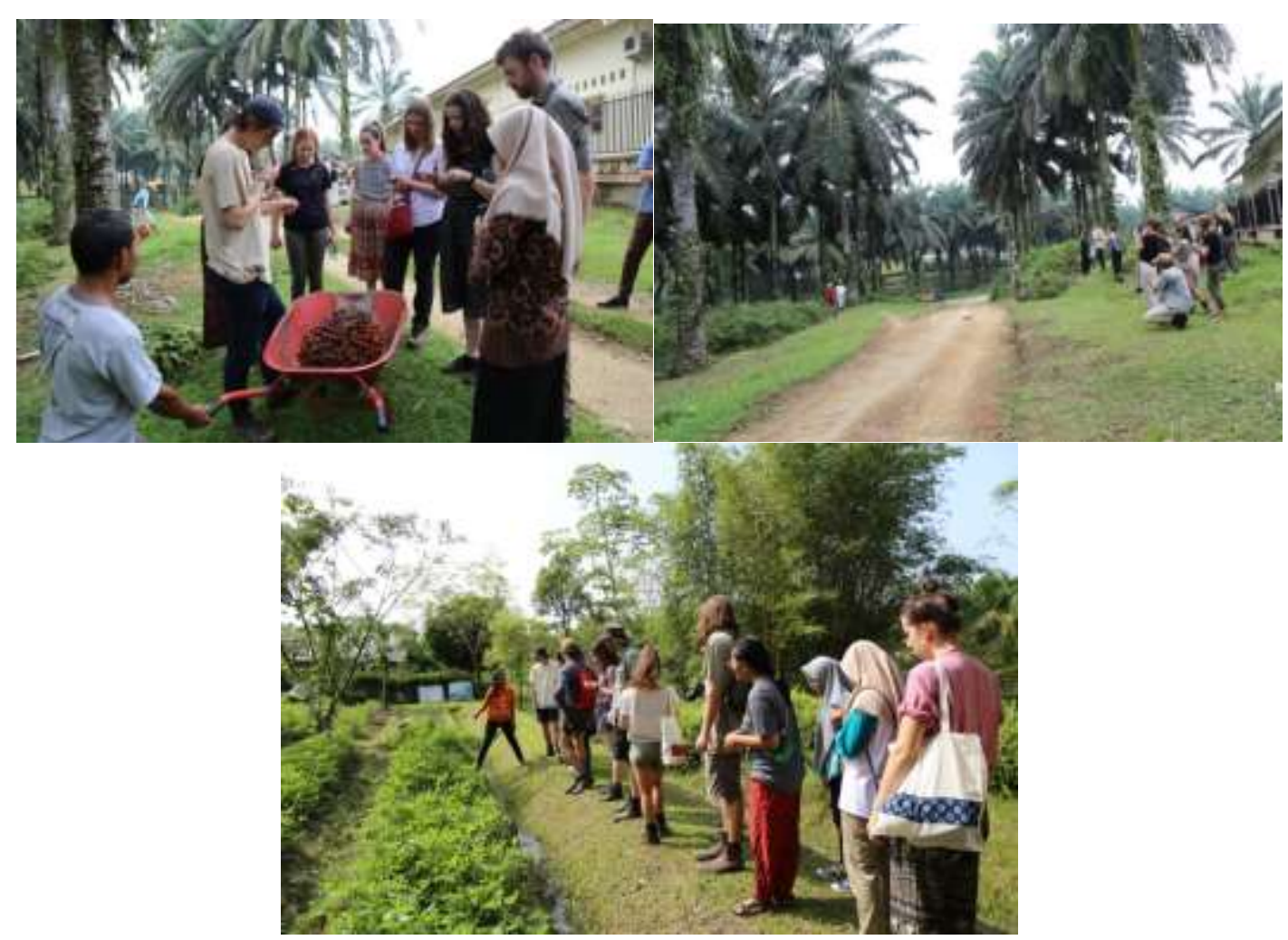

Figure 5. Site visit

\subsection{Day 3-7: 7 - 11 July 2019: Field Trip to Bukit Lawang}

Bukit Lawang is an orangutan rehabilitation site located in one of the oil palm plantations at centre districts, Langkat and close to the Gunung Leuser National Park buffer zone. The development of oil palm plantation is often considered endangered the orangutan survival. In Bukit Lawang, people can see healthy orangutans in their natural habitat. The students also planted trees in the buffer zone and learned about traditional ways in utilizing local resources, including those from oil palm trees.

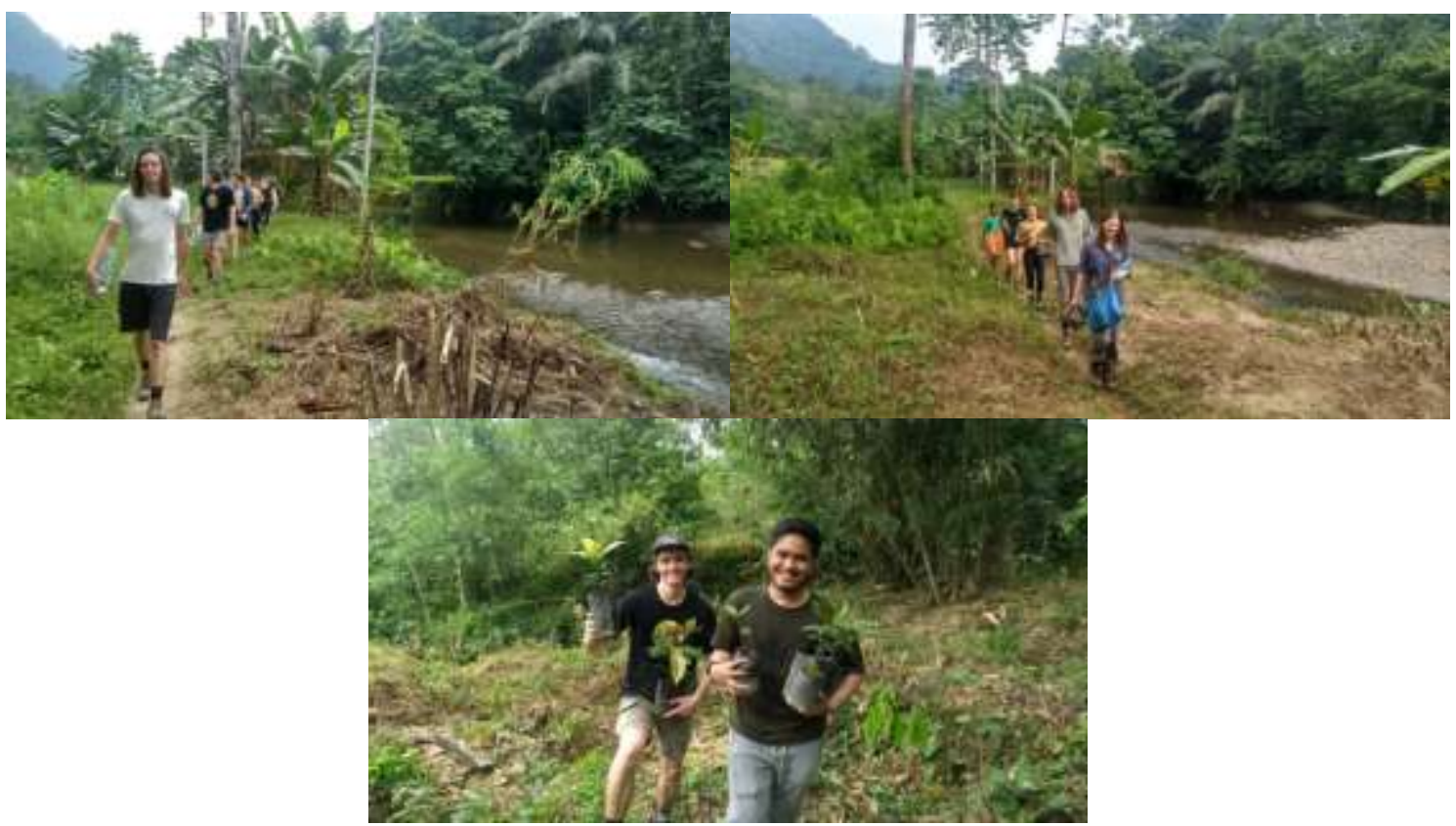

Figure 6. Tree planting 


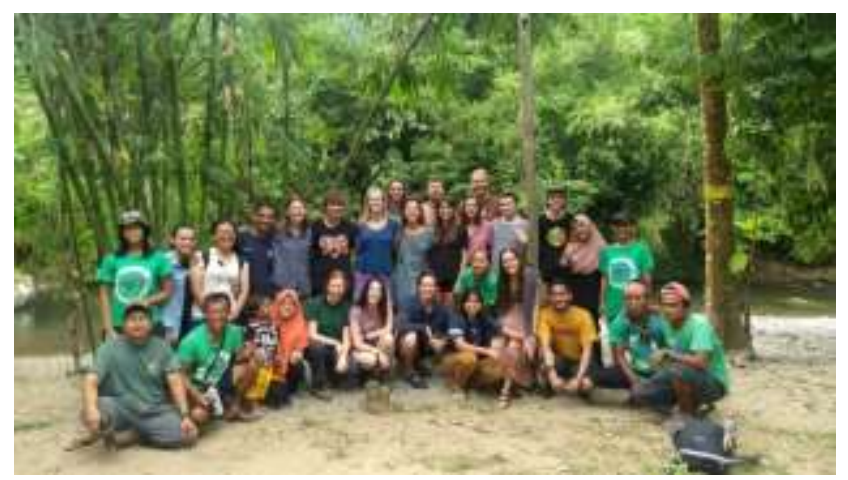

Figure 7. Participants and PPLH Staff

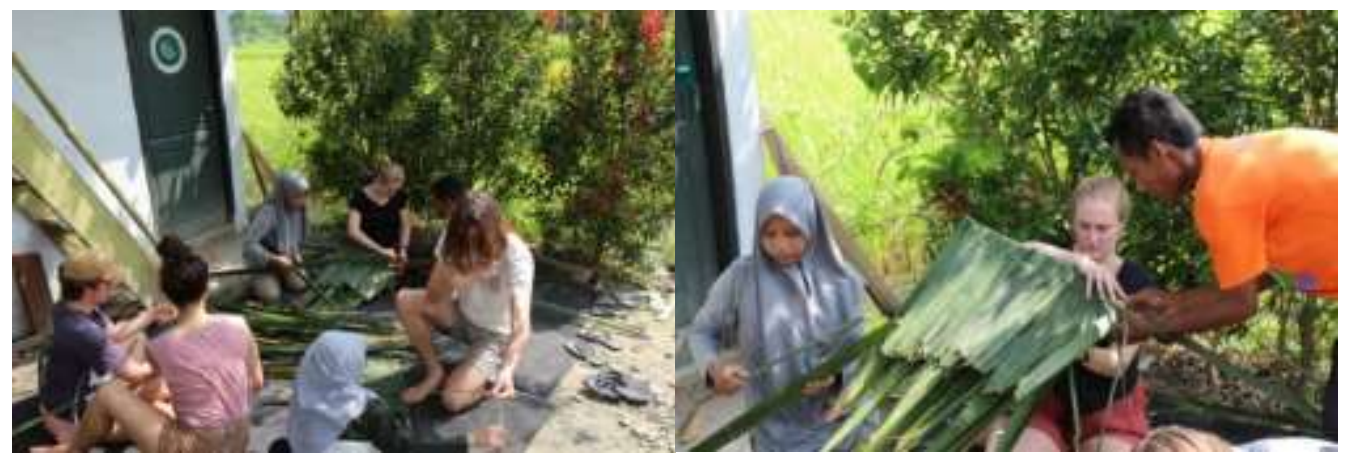

Figure 8. Learning about the local wisdom

\section{Conclusion}

Australia is one of the neighbouring Indonesian countries that consume a significant amount of vegetable oil. However, palm oil is not the primary vegetable oil used by Australians due to their negative perception. Some of the perceptions are not based on complete and robust information, thus filling this program to fill in the gap. Discussions and direct site observations appear to be sufficient in improving Australian consumers' perception of palm oil, which is expected to strengthen the Indonesian palm oil industry and export destination markets. Therefore, more similar programs are recommended to counter negative issues on the Indonesian palm oil sustainable management.

\section{References}

[1] Statistics Indonesia, Indonesian Oil Palm Statistics 2017, Jakarta, 2019.

[2] Ritschel, "The reasons why palm oil is so controversial," 2020. [Online]. Available:

https://www.independent.co.uk/life-style/palm-oil-health-impact-environment-ani mals-deforestation-heart-a8505521.html

[3] A. Rival and P. Levang, "Palms of controversies: Oil palm and development challenges," CIFOR, CIRAD, IRD co-publication, 2014.

[4] K. Mayberry, "Failing grade for companies dealing in palm oil: report," 2017. [Online]. Available:

https://www.aljazeera.com/news/2017/09/failing-grade-companies-dealing-palmoil-report-170920234741936.html. 
[5] J. Farmer, D. Knapp, and G. M. Benton, "An elementary school environmental education field trip: long-term effects on ecological and environmental knowledge and attitude development," The Journal of Environmental Education, vol. 38, no. 3, pp. 33-42, 2007. doi: 10.3200/JOEE.38.3.33-42.

[6] YEL, "Environmental Education," 2020. [Online]. Available: https://www.yel.or.id/environmental-education/. 